\title{
Budget woes cast chill on French research
}

Paris. Concern is growing again among researchers at France's publicly financed research institutes about cuts in government support. INSERM, the main agency supporting biomedical research, has just announced that it is freezing 25 per cent of the operating budgets of its laboratories.

It will be known at the beginning of April whether the money will be reinstated. At the same time, the Centre Nationale de la Recherche Scientifique (CNRS) has demanded the return of all the money held by its laboratories at the end of 1995 .

The CNRS has been in a critical financial situation for the past two years. It has had to face up to a heavy deficit resulting from the government's failure over several years to provide the funds for programmes it had promised to support.

In 1986, for example, the government of the then prime minister, Jacques Chirac, left unpaid FFr181 million (US\$36 million) owed to the research agency. Later, in 1991 and 1992, it was the socialists, faced with economic difficulties after their return to power, who held back a further FFr450 million. On top of this were various smaller unpaid sums of about FFr50 million. The figures were relatively low compared to the total CNRS budget of about FFr13 billion. Nevertheless, the overall deficit of the agency came to about FFr1 billion in 1994.

To meet this budgetary crisis, CNRS officials first demanded, in 1994, that its laboratories freeze 40 per cent of their operating budgets. Then, in August 1995, the government agreed to provide CNRS with an additional FFr300 million, while at the same time insisting that the agency drop FFr200 million of previously approved spending for "very old" programmes. Finally, last autumn, the government promised an extra FFr227.7 million in 1996 to cover previous commitments.

At the end of all this, the CNRS's deficit should total only FFr270 million this year, of which FFr90 million relates to laboratory projects and the rest to the operation of regional offices and the purchase of research equipment and buildings.

In order to eliminate the "very old" programmes, and to revitalize the projects that will benefit from the new money, the directors of the various departments within the CNRS demanded last month the return of all funds remaining in the accounts of individual laboratories. Eventually, the CNRS hopes that it will be able to recoup about FFr700 million.

Researchers and their unions are talking about a "hold-up", particularly as the money being reclaimed by the CNRS includes funds raised by individual laboratories through contracts paid for by outside organizations or industrial bodies, as well as from their reserves.
Pierre Tambourin, the director of life sciences at CNRS, and acting director while the permanent director general, Guy Aubert, is in hospital, has promised that the funds raised from outside will be returned. But "those who have made savings will lose them, while those who have overspent even if in good faith - will have to pay back what they owe". Tambourin adds that the agency "clearly indicated that funds allocated for 1995 had to be spent in full, but that those frozen in 1994 should not be touched".

As a result of these moves, some laboratories now find themselves faced with allocations for 1996 that have been significantly reduced - sometimes to a symbolic one franc. Such is the case, for example, with six out of 28 laboratories in molecular chemistry, and 8 laboratories in the life sciences section. Tambourin admits that this situation should not have occurred, as Aubert had required the repayment of the 'debt' of the laboratories to be made over two years.

But researchers have not taken kindly either to the measures that have been introduced, or to being accused, in particular by Aubert, of being bad managers of their finances. Jacques Fossey of the Syndicat National des Chercheurs Scientifiques (SNCS) feels, for example, that Aubert has been over-dramatizing the situation in order to build up a "war chest" to enable him to control the future policy of the agency.

Tambourin disputes such claims. But he acknowledges that the director general is keen, independently of budgetary problems, to ensure that the CNRS has a set of large programmes that are more significant than those it has been supporting up to now, costing about FFr300 million a year. The funds claimed back last month will be used partly to launch these programmes.

To achieve further cost reductions, CNRS officials are also renegotiating the contracts that link some laboratories to the universities in which they operate. Although most of these laboratories will continue to be linked to the CNRS on the same financial basis as before, between 20 and 30 per cent - those in which the number of university faculty members is higher than the number of CNRS researchers - risk seeing their formal association with the agency weakened, and their funding cut as well.

Catherine Tastemain

\section{Moroccan mineral is truly new and blue}

London. Scientists who were asked during Britain's National Science Week last year to investigate a blue powdery mineral purchased from a roadside stall in Morocco confirmed during this year's Science Week, which began last Friday (15 March), that the mineral (right) has not previously been identified.

The mineral's owner, Anna Grayson, a geologist and television presenter, enlisted the help of the mineralogy department at London's Natural History Museum after she tried - and failed to identify it herself. Initial X-ray diffraction tests confirmed that the mineral had not been described before. A team of researchers at the museum then began a series of tests to discover its structure and chemistry.

Viewed under an electron microscope, the mineral contains millions of crystals made up of sub-micrometrewidth fibres. Its chemistry was investigated by firing a beam of electrons into the crystals, which energized their atoms to emit X-rays. The mineral's atomic elements - including silicon, aluminium, calcium, magnesium, iron and oxygen - were identified by their characteristic $X$-ray energies.

The display of the mineral at the museum is one of 5,000 events taking place all over Britain as part of SET

\section{IMAGE UNAVAILABLE FOR COPYRIGHT REASONS}

'96, the National Week of Science, Engineering and Technology. This is an annual government initiative, coordinated by the British Association for the Advancement of Science and aimed at increasing public awareness of science.

The week is supported by industry, universities, schools and the media. Government ministers are using the occasion to promote both science itself and their current policies on how it should be supported. Opposition political parties have also lent their support, while pointing out that the UK government's spending on research and development has declined for the past decade.

Ehsan Masood 